\title{
SILENCING THE PAST, RETROTOPIA, AND TEACHING HISTORY
}

\begin{abstract}
The essay analyzes contemporary controversies connected with teaching history in Europe, with particular focus on Poland. It discusses contexts that condition the relation between academic, every day and school narratives about history, as it is taught in today's schools. These contexts are both political and ideological (historical policy), as well as-in a deeper sense-are an expression of national mythologies. The main thesis is the following: an analysis of teaching programs in schools tells us much more about the present than the past, and the main mechanism used to build a vision of national history is the notion of silencing the past. In our times, which Zygmunt Bauman has called the retrotopia, history becomes a bastion for nationalism and new tribalism.
\end{abstract}

Key words: history; nationalism; didactic transposition; retrotopia; nation; myth; memory

\section{UCISZANIE DZIEJÓW, RETROTOPIA I NAUCZANIE HISTORII}

\section{Streszczenie}

Artykuł analizuje współczesne kontrowersje wokół programów nauczania historii w różnych krajach europejskich, ze szczególnym uwzględnieniem Polski. Wskazany został kontekst różnic między historią akademicką, potoczną świadomością historyczną i szkolnymi narracjami o dziejach. Historia naucza-
WOJCIECH J. BURSZTA SWPS Uniwersytet Humanistycznospołeczny, Warszawa E-mail: wojciech.burszta@swps.edu.pl

CITATION: Burszta, W. J. (2018). Silencing the Past, Retrotopia, and Teaching History. Sprawy Narodowościowe. Seria nowa, 2018(50). https://doi.org/10.11649/sn.1656

This work was supported by the MNiSW (number 221548/E-560/S/2016) for Faculty of Arts and Social Sciences, SWPS University. No competing interests have been declared.

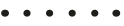

1 The article is a result of the research project MAESTRO no 2012/06/A/HS3/000266, entitled "The envisioning of nation in Polish history textbooks - a comparative anthropological study." The project leader is W. J. Burszta, and the research team consists of P. Dobrosielski, K. Jaskułowski, K. Majbroda and P. Majewski.

This is an Open Access article distributed under the terms of the Creative Commons Attribution 3.0 PL License (creativecommons.org/licenses/by/3.0/pl/), which permits redistribution, commercial and non-commercial, provided that the article is properly cited. (C) The Author(s) 2018.

Publisher: Institute of Slavic Studies, Polish Academy of Sciences 
nia w szkołach ma zarówno charakter polityczno-ideologiczny, jak i - w szerszym i głębszym sensie - jest wyrazem preferowanych wersji narodowych mitologii. Główna teza tekstu brzmi: analiza programów i sposobów nauczania historii więcej mówi o współczesności niż o historii w tym sensie, że metody i techniki akcentowania lub uciszania pewnych aspektów dziejów pełnią ważną rolę dla budowania określonej wizji tożsamości zbiorowych, dla których legitymizacją jest ideologicznie podbudowana "historia narodowa". Widać to także w kontekście pojęcia retrotopii Zygmunta Baumana. W ramach tej ostatniej historia staje się głównym bastionem dzisiejszych postaci nacjonalizmu i nowego trybalizmu.

Stowa kluczowe: historia; nacjonalizm; transpozycja dydaktyczna: retrotopia; naród; mit; pamięć

$\mathrm{n}$ excuse for the considerations made in this essay is our research project entitled
The envisioning of nation in Polish history textbooks - a comparative anthropologi-
cal study. The project originally focused on the role of school education in creating and sustaining the Polish national identity. We are interested in three issues: 1) past uses in school textbooks to promote and legitimize a specific vision of the past of Polish national identities, 2) the strategies for using textbooks by school teachers, 3) visions of the national community and its fate. Since 1989, we have been witnessing a dynamic process of replacing some narratives, myths and other symbols. They are continually interpreted as pluralizing ways of presenting the past, and these different visions of the past shed light on the transformations of socially important values, as well as culture and the principles of the national community.

It turns out that studying history textbooks is in fact a gateway to a much more complicated world - a world of ever-changing political imagination that has impact on what we should remember, and what we should forget about when we consider our national history. Teaching history means teaching a desirable version of a nation's history and identity. Today, a growing number of young people say that "we don't know who we are, or who we will become in the future, or how our world will look like, but we know one thing for sure-where our roots are, where we come from." These roots are understood as national roots. They form a basic foundation of certainty, a feeling of belonging. We can see this in the school education system, where this type of identifying with a national community is seen as essential. The levels of historical consciousness and historical knowledge of young Poles are not particularly high, however, on the other hand, a mythical perception of history remains very influential. We are constantly writing our history anew, adding new important figures and crucial events, while at the same time excluding or ignoring other heroes and events, which were equally important in the past.

It is necessary to take a closer look on these processes, which I will attempt to do in the following essay-an introductory, theoretical reflection on the complicated relationship between teaching history and the present.

Marc Ferro, in his classical book The Use and Abuse of History, a comparative study on the ways of teaching history in different countries around the world, makes a banal, it would seem, statement, which-as it turns out-is indeed a fundamental view for any consideration of history education in schools. He opens his book with the following sentence:

Our image of other peoples, or of ourselves for that matter, reflects the history we are taught as children. This history marks us for life. Its representation, which is for each one of us a discovery 
of the world, of the past of societies, embraces all our passing or permanent opinions, so that the traces of our first questioning, our first emotions, remain indelible (Ferro, 2003, p. ix). ${ }^{2}$

Teaching history in schools serves a dual role. It is both a form of therapy and a source used for promoting patriotism, which is understood as a logical conclusion: when a nation achieves self-awareness of its separateness and its need to form a country within specific geographical confines. Ferro cites Benedetto Croce, who at the beginning of the $20^{\text {th }}$ century was one of the first thinkers expressing the opinion that history is more inclined to show the problems of its current time than to tell us about any particular epoch it attempts to describe. Neither this pedagogical presentism, nor national teleology are random. When analyzing textbooks and teaching programs in several counties in the world, Ferro notices their double ethnocentrism (Ferro, 2003, p. xiv). By limiting only to processes and events observed from the European perspective, history is perceived only as being a history of the West, in addition to its "encounters" with the world extra muros of the continent. But the particular national histories are equally ethnocentric, as they describe the relations between "our" nation with neighboring countries and the complicated trajectories of conflicts and agreements with "others," defined as external to us. Naturally, the double ethnocentrism is different for past colonial empires, ${ }^{3}$ and different for the national histories of Poland, Wales, Ireland or Scotland, where the rule known as "West and the Rest" is also applicable. In the case of Poland the founding myth relates to the baptism of Mieszko I, depicted in textbooks as "the baptism of Poland" and successive accession into the Western world of values-irrelevant to what it could mean in the realities of early Middle Ages. ${ }^{4}$

To better understand the specificity of how the past is represented in history lessons, it is necessary to clearly distinguish three variants of such representations, and thusthree different understandings of the notion of "history." The first type is academic history or historiography, represented by professional scholars of the past, as well as social sciences and humanities scholars, who all perceive it as a disciplined logic of historical knowledge. The second type is history that is present every day, an element of collective memory, which becomes the basis of our systems of value, and is used to build subjective and cultural identity, common beliefs, myths and stories. And lastly-in some way, a byproduct of the first two-we have a representation of the past, a description of history written down in school textbooks, a way of telling and experiencing "our past."

It can be argued that these three types of representation indeed produce three distinct types of history, of describing independent stories, which can become a source of conflict. Nevertheless, as R. W. Sandwell points out, today it is difficult to elide from each of

\section{......}

The original French edition of the book was published in 1980. In a new short preface Ferro justifies why most of his diagnoses remain relevant, in spite of the important transitions happening at the turn of the 1980s and 1990s and the transformation of the political map of the world.

3 Michel-Rolph Trouillot writes that the concepts of modernity and modernization, which belong to the grammar canon of "universalities of North-Atlantic culture" (since it does not only relate to Europe), have a tendency to silence their own histories in the sense that the global expansion of colonialism creates two rivaling geographies-a geography of imagination and a geography of management. The first makes the notion of modernity appear in plural form, as it requires the existence of its contradiction, a reference to something which is not modernity-a pre- or non-modernity. Colonized societies and cultures become this required contradiction. That is why they are the subject of "modernization," of management, referenced as a secondrate geography. The notion of the West exist not only in the Euro-Atlantic culture, it is rather a space, not a specific place. Everything that happens in Europe extra muros is ascribed to a geography of imagination that relies on the struggles between modernity and non-modernity, and therefore becomes part of a specific poetic that explain the rivalry between European nationalisms which create a "civilizing mission." See: Trouillot, 2002, p. 220.

4 On the ambiguity of the "initial" event and the adaptive use of the occidental vision of the world, see: Urbańczyk, 2015. 
these representations, as they co-exist together and take part in the process of creating a "citizen," a person who from early childhood is being trained to participate in public life (Sandwell, 2006).

These three "regimes of imagination" and, above all, very diverse ways of constructing narratives about the past, refer to different levels of individual and common subjectivity. As Mario Carretero summarizes: „in brief: common identity principles define reality and validate a knowledge that is embodied-not only »learned "-by each member of the national collective, and compels them to take into account the relations they bear, whilst subjectifying and instituting the community in its vital experience" (Carretero, 2011, p. 4). Moreover-collective emotions are built precisely this way, by applying opinions about the past to everyday life and common sense reasoning to create a social and national habitus.

Academic history is still considered to be a guarantee and source model for the content of school textbooks, naturally after undergoing a process of adaptation-connected with its transposition for didactic purposes. Many pedagogues believe that the relationship between "academic knowledge" and "knowledge taught in schools" is based on a number of essential and significant changes that have to occur in the former, in order for the latter to be considered successful. This happens for two main reasons. Firstly-it is assumed that academic, professional historical knowledge is too complex and abstract. Secondly, school methods of teaching in principle have to transform these complex matters according to the strategy of "didactic transposition," which sets a peculiar tone to teaching history: it focuses on instilling an emotional, or even intimate (indeed-metonymic) "adherence" to symbols of national identity. This is always accompanied by a loss of critical thinking, since historical knowledge, as it is taught in school, goes as far as only simulating the real potentiality and complexity of described events (See: Grever \& Stuurman, 2007). According to Carretero, history taught in school is simultaneously something more and something less than academic history. It is less factual, less interpretative and contextualized. But it also does much more, as it encompasses an enormous space of values connected with some threads of the historical narrative. Its primary objective is the creation of a positive image of national identity (Carretero, 2011, p. 5). It can have a triumphal, developmental, or sometimes messianic undertone, and remains in strong, albeit rather informal, relation with patterns of collective memory which are either promoted and supported, or-as in Poland after 1989-remembered and appreciated, in an attempt to build from scratch a new canon of knowledge about the past; one which prefers particular values. This does not refer only to the content of school textbooks, but also curriculums, persuasion towards teachers (or their own initiative) and many other worldview operations whose ultimate objective is the promotion of a preferred ideal of patriotism. ${ }^{5}$

Let us analyze one significant example: a thematic contents for junior high school pupils in Mazowsze, organized in 2017/2018. The title: "Famous and unknown heroes of the opposition of the 1970s and 1980s." The content has several subsections, and some of the figure mentioned as worthy of discussion are: "Andrzej Gwiazda, Lech Kaczyński, Jan Józef Lipski, Antoni Macierewicz, Karol Modzelewski, Kornel Morawiecki, Jerzy Popiełuszko, Grzegorz Przemyk, Zbigniew Romaszewski, Anna Walentynowicz". Neither Lech Wałęsa, nor Adam Michnik or Jacek Kuroń are mentioned. The content clearly shifts accents, eliminating memory about KOR and mythologizing "regular Poles"; the section for "teachers and parents" states that: "historical heroes did not consist only of oppositionists presented in history textbooks, or in popular media. Thousands of brave people all around the country, active in the last two decades of the People's Republic of Poland, have not been active in politics after the year 1989." In turn, the newly introduced history programs for schools put substantial more emphasis on the "Cursed Soldiers" (Żotnierze wykleccl), positioned as longforgotten heroes. 
Marc Ferro has analyzed in detail how history was taught in Polish schools since 1945, referring to, among others, a meticulously written text entitled "Realization of educational tasks in history lessons in primary schools," authored by Józef Olszewski, a prominent member of the Polish United Workers' Party, as well as analyzing chosen textbooks from the 1960s and 70s. The French historian-while noticing that the clock of our countries' political history has stopped at the end of the Second World War-discusses the grotesque way of teaching Polish history in that period, its specific profiling, etc. (Ferro, 2003, pp. 245-267). For today's generation of school pupils, many of the heroes from the past archipelago of values are completely unknown, exotic, or even function as national enemies... It is worth mentioning not because Ferro had discovered something that was unknown to us, but for an entirely different reason. By confronting what was taught then with a whole spectrum of history textbooks published after 1989, it is possible to show that-contrary to what was officially declared in the heated period of the transformation-not a lot has changed in terms of the logic of thinking about the past in the context of the present, and how it is employed in school education.

In the introduction to his excellent article Gtówne narracje o przeszłości Polski po 1945 roku. Próba charakterystyki, Rafał Stobiecki quotes a passage from Przemysław Czapliński's book, in which the literary scholar argues that society exists only as an exchange of narratives, constantly transforming, competing with each other and always incomplete (Stobiecki, 2009, p. 67). ${ }^{6}$ Stobiecki, while agreeing with this opinion, restricts himself only to the field of historiography-or, to be precise, to the three types of stories (which have the status of meta-narratives) that organize collective history, giving it direction. He adds that it "is a scheme for interpreting and writing history. From this point of view I think that, in relation to historiography, it can be compared with such categories as "a synthesis of Polish history" or "the concept of national history «" (Stobiecki, 2014, p. 68). ${ }^{7}$

The historian calls the first story "a narrative of unfulfilled promise." According to the Marxist paradigm imposed on historians after 1945, it was a legitimization of the existing social and political order, and a reason for the country's new political organization after the Second World War. This narrative was based on the revolutionary idea of "a new beginning": it was considered a breakaway from the tradition of historiography, one that forced to search for different origins, "both in the sense of the history of the world, as well as Polish history" (Stobiecki, 2014, p. 68).

The second type of story recognized by Stobiecki is an "unbroken narrative," characterized by him in the following words:

It was shaped in opposition to a Marxist view of history, invoking values which can be defined as "traditional." In its different variants, it referred to distinct methodological assumptions, while also carrying other ideological messages. Its guiding thought was the idea of continuation, understood as a widely framed defense of the pre-war status quo and the preservation of those elements which dominated in the image of Polish history in the period 1918-1939 (Stobiecki, 2014, p. 68).

The third type of story is a "revisionist narrative," existing in many competitive variants which nonetheless carry one common assumption, that is- "Polish history has to be told anew" (Stobiecki, 2014, p. 68). The debate about the last meta-narrative, discussed

6 Stobiecki is referring to the book by P. Czapliński, Polska do wymiany. Późna nowoczesność i nasze wielkie narracje (Czapliński, 2009).

7 This type of story about Poland was preferred, and often still is, by Polish historians working in other countries. A detailed bibliography is presented in the quoted article. 
at length in Rafat Stobiecki's article, has many shades and colors, stretching from the field of nationalism to-let us call it-a critical revisionism that questions many episodes from the past (Jedwabne, relationships between Poles and their neighbors etc.), and is obviously also expressed in some way in school history lessons. Not without significance, as Stobiecki points out, is the fact that "no alternative vision of the presence of history in public space was created, one that would be positioned against the slogans of historical policy realized in the period 2004-2007, and the dominance of the dichotomous " us " and »them « formula applied to every discussion in the field." (Stobiecki, 2014, p. 68).

Today, more than a decade later, we might even go as far as to say that the attempt to ascribe our national history into a wider context-whether it is European, regional, or civil-is on the defensive. Values connected with multiculturalism, tolerance, or gestures towards a more empathetic connection with the Other, or even the idea of dialogue, which all in all are the intentional objective of revisionist narratives, have not been in any way reflected in history education-neither in textbooks, nor in didactic practices of teachers (See: Jaskułowski \& Surmiak, 2015). ${ }^{8}$

Before moving to further considerations, I will allow myself a small detour-a look on the analyzed problem from the perspective proposed by the anthropology of suspicions, as I would like to call the supposition that academic, everyday and school history all equally share common features which stem from the symbolic imagination that is anchored in myth. I would argue that the coexistence of these three types of histories has one additional and important aspect. It is the presence of myth and mythologizing processes, apparent even in certain prejudgments of "historical policies" that do not hide their ideological positions. From the point of view of the anthropology of suspicions, this way of thinking about history and national memory can be analyzed from a slightly different perspective. As far as Robert Traba, being a historian, convincingly analyzes the logic underlying the discourse of historiography and the way of thinking according to which historiography is secondary to politics (Traba, 2009, p. 33), the anthropological reading in fact argues that it is always secondary to myth - a constantly-actualizing declaration on the worldview and "the logics of history." And, moving further: every transposition of academic history for the needs of school education is simultaneously a transposition of certain myths.

In The Social Role of the Man of Knowledge, Florian Znaniecki described a category of people which he called "sages," who are guides that specialize in the problems of cultural order (Znaniecki, 1986). I have argued elsewhere about the possibility of applying the figure of the "mage-sage" to the analysis of contemporary politics that deal with clashes between liberal and conservative-minded bearers of historical knowledge (See: Burszta, 2015, pp. 2-14). To summarize it in short: the duty of a sage is to "prove" that the ultimate "truth" he is bound to represent (and popularize) is in fact aligned with what is considered to be "good," in contrast to the "evil" that his opponents, who represent the older cultural order and system of meaning, would see as being the truth. In order to do so, the mage uses language that always refers to a magical source, giving himself advantage over any "normal" language; because of this, he is able to replace logical arguments (e.g., historical facts) with slogans and spell-like persuasions.

Strengthening this way of thinking is dangerous from a cognitive and political standpoint. And that is basically what the right-wing and conservative historiography is proposing today, additionally coloring it by making connections with a specific understanding of

\section{-...・}

8 For example, see: Jaskułowski and Surmiak (2015). 
what defines Polishness (ethnical and catholic). It is dangerous from the cognitive perspective because, as we can see, it turns history into myth. Naturally, the distinction between history and myth is not as clear as positivist-oriented scholars would like to think; it is rather a sort of continuum. Using the category of myth does not equate it with a false narrative about the past, but, contrary to history, a myth frames the past as existing in the same temporal setting as the present. A myth goes beyond the past which is understood as a sequence of events. It moves us into the realm of absolute values which exist eternally, unconstrained by the passage of time. An important element of myth is therefore the idea of continuation, or even immutability. A continuation between the past and the present is assumed automatically (and not proven): the question of continuity is left outside of discussion or critical reflection. There is no difference between yesterday and today. An so, despite the passage of centuries, we are always faced with an identical collective subject-a homogeneous Polish nation-which must protect its traditional way of life, existing for centuries, from any foreign influences. A myth blurs the differences between epochs, e.g. by juxtaposing historical figures from different periods who represent emotionally-loaded symbols of certain attitudes or ideas: a hero, a martyr, a defender of Polishness vs. coward, an oppressor, a traitor. This way of thinking does not lead to an understanding of the past, but kills it (See: Carretero, 2011).

In Poland, the last couple of years have been characterized by a growing dominance of this perspective on national history, as it is expressed in each of the three types of metanarratives, aided by an additional ally-the right-wing, conservative and Catholic media (significantly self-identifying exclusively as "national"). This makes it impossible, especially for pupils, to view the historical process as a complex and multi-faceted consequence of the collective actions of people, often motivated by ideas very distinct from our own. It also fails to explain the role of social conflicts in history, which in turn translates into a lack of understanding for the modern democratic society-a space of conflict, of clashes between different attitudes, values, interests. Finally, a mythologized vision of history that is then applied to school education goes against the need to educate future citizens who will be aware of how complex societies function (also through conflict). Mario Carretero's important book indeed discusses these issues at length from a comparative perspective.

All in all, what has been discussed so far refers in its entirety to a vision of teaching "proper" history, which is supposed to be a history of "truth"-a truth that suits the opinions and political meanings attached to society today. This problem is addressed in Georges Mink's unsettling book, in which the French political scientist and sociologist characterizes the following features of Polish (mythologized) historical policy:

An attempt to introduce changes in the Polish national pantheon could be compared, toutes proportions gardées, to a similar act of trying to affirm, in contemporary France, that de Gaulle did not achieve anything, or, by allying with the allied powers, indeed proved himself to be a traitor of the French nation. Of course Lech Watessa is no de Gaulle. I use this example only to show the true scale of historical revisionism we are currently observing taking place in Poland, where the historically-validated architects responsible for the country's exit from communism are supposed to be replaced by the diseased president Lech Kaczyński and a number of other figures who were always faithful to the Law and Justice party (Wałęsa is stripped of this position, and replaced by Anna Walentynowicz, admittedly an undisputed hero of the strike which became the foundation of the "Solidarity" movement, who nevertheless does not deserve to be called a true leader; Kuroń and Michnik share a similar fate, and the nationalist and conservative Macierewicz is promoted, etc.) (Mink, 2017, p. 580). 
This quote brings us to the problem of silencing the past, a concept introduced most clearly by the Haitian anthropologist Michel-Rolph Trouillot. Analyzing the most radical revolution that occurred on his home island at the turn of the $18^{\text {th }}$ century, a revolution that ended slavery and influenced the birth of a new country ruled by Mulattos, Trouillot shows how the silencing of the past is done by eliminating/marginalizing/trivializing different historical phenomena in the process of producing knowledge about the past. This happens in four dimensions: at the moment of choosing facts (creating sources), at the moment of gathering facts (creating archives), at the moment of exposing facts (creating narrative), which ultimately leads to retrospectively adding meaning to a chosen set of historical statements, which is known as writing history (Trouillot, 1995, pp. 26-27). In other words, every historical narrative at the same time functions as a process of revealing and creating sets of concealments, the latter requiring deconstruction in order to situate them within a broader process of constructing ideas about the logic of history. As Michel Foucault has taught us, an essential element of every historical narrative which claims the right to impartiality and objectivity is the issue of power. History, then, endows us with "clues" and traces, but constructs them also through silencing anything that is considered less significant. This is what happened in Haiti. Firstly, the chain of events that in its entirety came to be known as "the Haitian Revolution" was impossible to understand before the events had come to a conclusion, since history did not know of any similar "set" of facts. Secondly, at the moment when these events were taking place, they were systematically reshaped according to the hitherto logic of how slavery was perceived in the colonies.

That is why-writes the Haitian anthropologist-there was an attempt to either "erase" this event from the collective memory of Europeans, or to trivialize it as much as possible. Indeed, both strategies are ways and methods of silencing and concealing. Trouillot is not afraid to draw equivalencies between the revolution in Haiti and the Holocaust, when he writes that in both examples the strategy of silencing followed a similar pattern: either "nothing happened," or "it was not that horrible, not that significant in the face of much more important events." From our perspective, this understanding of the silencing of the past can be seen happening in Poland today. What Ferro had analyzed in the context of teaching history in the People's Republic of Poland, for today's revisionist historians seems like a scandal, set of facts that "must be forgotten." Their place will be taken by an archipelago of new and old heroes ascribed into the mythical continuity of history. We can thus say that the construction of a canon of knowledge about the past is always "bulimic" by nature: together with ideological transformations, each surplus figure or event is replaced with by a similarly uncontrollable appetite for "writing history anew."

Using inspiration from Enzo Traverso's book Historia jako pole bitwy [History as Battlefield], it is worth noticing that in the context of the new world mosaic that appeared after 1989, social sciences and historiography in the last decades have sketched out an outline of a new approach to the modern world, in many ways transcending the boundaries of historical research. To quote Traverso:

There are constant tensions arising between the past and the present, between history and memory, between experts' opinion and public use of the past. The academia is not the only place where they take place, since they move into the realm of media understood in the broadest possible sense [...] History is always ascribed into the present. In reality, numerous historical works tell us more about their epoch, portraying the past world of imaginings and ideas, than about the past which secrets it wishes to know (Traverso, 2014, p. 12). 
The transatlantic model of civilization is no longer adequate to the perspective of the $21^{\text {st }}$ century, but nevertheless seems to still dominate in how we teach history, which in Europe is paradoxically returning to its romantic, ethno-nationalistic and stubbornly ethnocentric roots.

The most interesting aspect of these considerations is what could be called a condensation of memory, a particularly interesting crossroads of memory and history that in many ways influences the strategies and tactics applied to the teaching of history. Traverso openly declares:

The solidified time of the Cold War has passed, paving the way for the possibility to reveal numerous memories which, up until that time, have been censored, made secret or repressed. Memory, situated in the new paradigm of approaches to the modern world, has pushed to the background the notion of society, which from the 1960s to the 1980s seemed to be the guiding principle explored in historians' offices. Memory, until now used only by certain proponents of oral history, has suddenly achieved the status of both source and subject of historical study, even becoming a sort of fashionable label, a well-worn word, often used as a synonym for history (Traverso, 2014, p. 17).

We can identify four rules for recreating history in the present, the absence of which is conspicuous when we study the paradigm of mythologized historical policy:

[1] Rule of contextualization: placing an event or idea in their epoch, considering their social framing, intellectual and linguistic surrounding, mental landscape.

[2] Rule of historicism: referring to real historicity that surrounds us, a necessity to approach facts and ideas from a diachronic perspective that captures transformations in time. This rule is based on an opposition to classical historicism and the positivist assumption that "history does not have its own sense which would emerge from it only through a close reconstruction of facts" (Traverso, 2014, p. 17). Walter Benjamin warned against this when he argued for a critical historicism which would promote an apologetic vision of the past instead of a history written from the point of view of the winners.

[3] Rule of comparison: comparing events, epochs, context, ideas is a necessary step in the process of understanding. For instance, it applies to such concepts as race, slavery, nationhood (See: Burszta, 2017b, pp. 25-37).

[4] Rule of conceptualization: in order to understand reality, it must be considered using notions and ideal types, while not abandoning a narrative way of framing history. Reinhart Koselleck's (2001) outstanding writing, including his Semantyka historyczna, can be considered a model for this paradigm.

To put it simply: the past is always reproduced, analyzed and interpreted in the present, and so writing history-or, more precisely, writing political history-is part of, as well as limited by, what Jürgen Habermas called the "public use." History-as Benjamin wrote-is not only a discipline, but also a form of remembering. Koselleck also emphasizes this point: in the short run history can be written by winners, but in the longer run any cognitive benefits we may learn from it must come from those who have been defeated (Traverso, 2014, p. 27).

Today's revisionist, "national" historiography, presenting and defining itself as victorious, must "silence" everything that is critical towards it, also on the level of school and in the process of shaping common assumptions about history or specific "figures of memory." Historical policy plays a specific role in this program of re-educating, especially when it is applied to school education. For Poland to become Poland again, we must restore our own history. Furthermore, the right-wing argument is based on a completely false 
assumption: the modern school system, and especially history lessons, does not teach patriotism. An analysis of history textbooks, as well as qualitative research among teachers and quantitative research among both pupils and teachers, clearly demonstrate that one of the primary objectives of teaching history is the promotion of patriotic attitudes, including respect for national symbols, loyalty for the Polish nation, the idea of national consciousness, or the responsibility to act in order to protect the country. In its present condition, history education in schools is based on the presumption that it needs to help build a national community-an opinion that is shared by history teachers (Jaskutowski \& Surmiak, 2015). Indeed, it is rather difficult to imagine even more patriotic textbooks or history lessons than the ones we have today. A similar trend characterizes teaching history in Western Europe, phenomena discussed at length in Mario Carretero's brilliant book, as well as many other studies detailing the public debates on history education (See: Nakou \& Barca, 2010).

If history lessons in schools in fact are short of anything, it is a critical reflection on the Polish nation. Critical not in the sense of only exposing the dark episodes of our history, but in exploring a historical analysis that would trace the origins of the idea that such a thing as "our history" exists in the first place. And also: what does it mean-"our," or what do we make of such worn-out and automatically used pronouns as "we," "here," "ours," more than ever when dealing with processes of inclusion and exclusion. To put it differently, the main framework for teaching history in schools is a transcendental and ontological category of the nation which, in a way, exists beyond temporality. Despite the passage of centuries, we are still working around the same collective subject, defined in essentialist categories which exclude any type of minorities, or treat them with distrust (See: Burszta \& Jaskułowski, 2016, pp. 8-12).

When framed within teleological categories, the history of Poland is perceived as a process determined by the end result-the creation of an independent Polish state. The history of the Polish nation is a continuous battle for freedom, its symbols being kings, knights, soldiers and politicians. Historical figures are considered as moral examples: what is important is whether a figure served its nation or did not, therefore becoming a traitor. What we lack is not a way of teaching patriotism, but a study of patriotism itself: a historical look at the category of nation, and the way the presumption that a nation is the most important community-one worthy sacrificing one's life-was shaped throughout history. At present, history education is largely characterized by an ahistorical approach, within which belonging to a nation is seen as something natural, and therefore loyalty towards a nation sets the confines for what we consider to be moral. In other words - it is still functioning within the mythological register of imagination.

Because of this I have to agree with Ludwik Stomma, who in one of his books that dealt with history education wrote the following words:

In that sense a myth sheds light on the social consciousness present in almost every national and state community. Poles here are no exception, although in our case the mythological education is particularly revolting, often using grotesque forms which encourage only collective self-satisfaction. That is why I believe we should challenge these myths, slander any sanctities (Stomma, 2006, p. 5).

More than ever, these words seem current in the times of retrotopia, which was the subject of Zygmunt Bauman's last book written before his death (Bauman, 2017; Burszta, 2017a, pp. 15-28). 
What is retrotopia? It is a combination of the terms "utopia" and "retro," and in Bauman's reading refers to the paintings of Paul Klee and their interpretations proposed by Walter Benjamin. The latter scholar was influenced by this concept when he created the famous intellectual figure of the Angel of History. Benjamin attempted to point out to any over-optimistic eulogists of progress that we are not attracted by the glows of future, but on the contrary, by the dark shadows of the past which force us to escape. In this sense, the direction towards future is in fact primarily a means for escaping the past.

While the original angel of Klee was repelled by the disgust to the atrocities of the past, today's angel-as Bauman teaches us -is transformed into a figure which blindly runs forward, because of the fear of... the future. To put it differently: retrotopia means a turn towards some visions of the past, a nostalgic return to a reality which is perceived as safe, understood and, what is equally important, stable precisely because it is predictable. It characterizes communities as well as individuals, and is a search-undertaken for many different reasons-for certainty and an escape from the unknown. People tend to think that a return to the past is not only possible, but can be seen as a successful remedy for today's troubles and the permanent fluidity of our globalizing reality.

The world of the second decade of the $21^{\text {st }}$ century is anti-utopian, full of disbelief that the future can bring real and true progress, or improve the collective or individual being. On the contrary, it is characterized by a nostalgia after past times that from today's perspective seem to be desirable, because they were already proven to be successful, even if they were full of violence and cruelty. The past is idealized and approached very selectively, as "our" past. The past has already happened, so we cannot make any more mistakes-contrary to the future, which is open to our mistakes! What is more, the past can be manipulated, as it is commonly done. The lack of belief in the future-says Bauman-fuels retroutopian tendencies, spilling into every possible part of individual and collective life. Bauman's Retrotopia is an introduction-and inventory and description of the concept, the last metaphor that the philosopher has left for us to reflect upon, analyze and critically address.

Bauman described the sentiments and practices of retrotopia in four dimensions: return to Hobbes, return to tribes, return to inequalities and return to the womb. It is similar with the colors and tones of retrotopia. We can approach it from the perspective of a specific return to Hobbes' idea of "war of all against all", which does not mean that in the beginning of the $21^{\text {st }}$ century we are in fact returning to the state of nature. What the $17^{\text {th }}$ century philosopher had called the social contract (and metaphorically represented by the figure of the Leviathan), still exists today-in the form of multiple, competing and often imperfect rules and regulations, mutual distrust, the popularity of conspiracy theories and cultural wars. Everything seems to be getting worse. The future no longer promises anything better, so there is no safer choice than to return to our fantasies about a much better time in the past.

One of the answers to this permanent state of uncertainty and troubling fluidity is a return to the reality of tribes - a more and more common reaction to our contemporary world which is deregulated, lacks any clear center, is multicultural and overwhelmed by the fear of the future. Bauman analyzes contemporary nationalism, the growing popularity of populist sentiments in the world, but, all in all, shows us how the anthropological division between "us" and "them" is written anew and multiplied into more variantsfrom defending national identities and the heritage of ancestors (always "our" ancestors"), and ending with online communities which are not-contrary to what some peo- 
ple hoped for few years ago-communities that encourage emancipation, understanding or dialogue, but create-as I like to call it-a new version of the homo barbarus (Burszta, 2016, pp. 5-19). We all can experience the effects of this en masse rejection of any forms of universality, as everyone is trying to protect themselves only within the boundaries of their own territory, and by calling upon the weight of their own heritage-this, and nothing more. Instead of global solidarity, the response is an investment in, and a defense of, a local monoculture.

Translated by

JĘDRZEJ BURSZTA

\section{REFERENCES}

Bauman, Z. (2017). Retrotopia. Cambridge: Polity.

Burszta, W. J. (2015). The frontiers of identity, the identity of frontiers (J. Burszta, Trans.). Sprawy Narodowościowe: Seria Nowa, 2015(47), 2-14. https://doi.org/10.11649/ sn.2015.050

Burszta, W. J. (2016). Homo barbarus w świecie algorytmów. IDEA—Studia nad strukturą pojeć filozoficznych, 28(2), 5-19. https://doi.org/10.15290/idea.2016.28.2.01

Burszta, W. J. (2017a). Płynność i retrotopia. In A. Kisielewska, A. Kisielewski, \& M. Kostaszuk-Romanowska (Eds.), Przyszłość kultury: Od diagnozy do prognozy (pp. 15-28). Białystok: Wydawnictwo PRYMAT.

Burszta, W. J. (2017b). Uciszanie przeszłości-niewolnictwo-antropologia. Filo-Sofija, 17(36), 25-37.

Burszta, W. J., \& Jaskułowski, K. (2016). Uciszanie krzykiem: W drodze ku Polsce Wielkiej i Zawsze Niezłomnej. Odra, 2016(4), 8-12.

Carretero, M. (2011). Constructing patriotism: Teaching history and memories in global worlds. Charlotte, NC: Information Age Publishing.

Czapliński, P. (2009) Polska do wymiany: Późna nowoczesność i nasze wielkie narracje. Warszawa: W.A.B.

Ferro, M. (2003). The use and abuse of history: Or how the past is taught to children. London: Routledge.

Grever, M., \& Stuurman, S. (Eds.). (2007). Beyond the canon: History for the twenty-first century. New York, NY: Palgrave. https://doi.org/10.1057/9780230599246

Jaskułowski, K., \& Surmiak, A. (2015) Teaching history, teaching nationalism: a qualitative study of history teachers in a Polish post-industrial town. Critical Studies in Education, 58(1), 36-51. https://doi.org/10.1080/17508487.2015.1117006

Koselleck, R. (2001). Semantyka historyczna (W. Kunicki, Trans.). Poznań: Wydawnictwo Poznańskie.

Mink, G. ( 2017). Polska w sercu Europy od roku 1914 do czasów najnowszych. Historia polityczna i konflikty pamięci (M. Kozłowska, Trans.). Kraków: Wydawnictwo Literackie.

Nakou, I., \& Barca, I. (Eds.). (2010). Contemporary public debate over history education. Charlotte, NC: Information Age Publishing.

Sandwell, R. W. (2006). To the past: History education, public memory, and citizenship in Canada. Toronto: University of Toronto Press. 
Stobiecki, R. (2014) Główne narracje o przeszłości Polski po 1945 roku: Próba charakterystyki. In E. Domańska, R. Stobiecki, \& T. Wiślicz (Eds.), Historia - dziś: Teoretyczne problemy wiedzy o przeszłości. Kraków: Universitas.

Stomma, L. (2006). Polskie złudzenia narodowe. Poznań: Sens.

Traba, R. (2009). Przeszłość w teraźniejszości: Polskie spory o historię na początku XXI wieku. Poznań: Wydawnictwo Poznańskie.

Traverso, E. (2014). Historia jako pole bitwy (Ś. F. Nowicki, Trans.). Warszawa: Książka i Prasa.

Trouillot, M.-R. (1995). Silencing the past: Power and the production of history. Boston, MA: Beacon Press.

Trouillot, M.-R. (2002). The otherwise modern: Caribbean lessons for the savage slot. In

B. M. Knauft (Ed.), Critically modern: Alternatives, alterities, anthropologies. Bloomington: Indiana University Press.

Urbańczyk, P. (2015). Zanim Polska została Polską. Toruń: WN UMK.

Znaniecki, F. (1986). The social role of the man of knowledge Columbia University Press. 